\title{
A Critical Ethnography of Myanmar Migrants' Grassroots Multilingualism at a Chinese Massage Parlour
}

\author{
Zhijuan $\mathrm{Ni}^{1}$ \\ ${ }^{1}$ School of Foreign Languages, Yunnan University, Kunming, China \\ Correspondence: Zhijuan Ni, School of Foreign Languages, Yunnan University, Kunming, China. E-mail: \\ NZJ0Eurus24@163.com
}

Received: July 16, 2021

Accepted: July 28, $2021 \quad$ Online Published: August 30, 2021

doi:10.5539/ass.v17n9p11

URL: https://doi.org/10.5539/ass.v17n9p11

\begin{abstract}
While China is broadening its gateway into South Asia and Southeast Asia, millions of foreign migrant workers cross the border and seek their transnational fortune in China's border provinces. However, within the existing literature in migrant workers in China, language is rarely a research target in itself. As one of the important social actors language plays a key role shaping migrant workers' life trajectories. Adopting Spolsky's language policy theory and following the critical ethnography with migrant workers (Han, 2013; Mathews, 2011), this study explores the interplay of national polices of massage parlour management at a macro level, employers' stipulations of managing Myanmar migrants at a meso level and Myanmar migrants' language practices at micro level. Grounded upon critical sociolinguistic ethnography, data is collected from a China's massage parlour at border town through the participant observation in and out of massage parlour, field notes, semi-structured interviews and documents. The study probes into how Chinese geopolitics of the wider process of regional development facilitates or constrains Myanmar migrants, how they mobilize social resources to expand their multilingual repertoires and how Chinese employer manages Myanmar migrants in language and life aspects. Findings reveal that there is no specific language policy at the recruitment stage. However, when Myanmar migrant workers start to work, language emerges as implicit but powerful medium streaming the likelihood of upward mobility. Other social factors, such as gender, nationality, religion and class also influence their mobility and integration into China's local society. The study expands the understanding of language management and grassroots multilingualism in the context of globalization from below. Also the study provides implications on language policy making, migrants integration and education for migrants of multilingual backgrounds.
\end{abstract}

Keywords: language management, language practices, grassroots multilingualism, Myanmar migrants, massage parlour, Ruili

\section{Introduction}

Migration is an irrevocable trend of globalization. The improvement of China's economic and international status appeals numerous migrant workers to come to China in the context of globalization from below. China is transforming itself from migrants sending country to migrants receiving country. What's more, China's Belt and Road Initiatives (B\&RI) have attached more importance to other Belt and Road countries. Some universities in China border regions have developed more suitable less commonly-taught foreign language programmes responding to national policy calls and needs. Due to the unique geographical advantages, Yunnan province serves as one of the frontiers of Opening-door strategy. With abundant culture and language resources, border areas are crucial for entire China to enhance cooperation with neighboring countries in economy, diplomacy and culture.

Myanmar shares around 2,200 kilometers borderline with China. Situated in the intersection of South Asia and Southeast Asia, Myanmar provides China the shortest way to enter the Indian Ocean. Also China is a crucial trade partner of Myanmar, which means great strategic meaning for mutual countries. Yunnan's total value of imports and exports of border trade (2019) is 3,108 million. Yunnan's total value of exports to Myanmar from 2018 to 2019 has increased $11.1 \%$ and total value of imports increases by 33.8\% (Source: Yunnan Statistics Bureau, date: 2021-05-13).

Moreover, more foreign enterprises enter Chinese market and more international interactions occur, which leads to increasing attention in workplaces communication on language choice in multilingual workplaces. Ruili is one 
of National Key Open Test Zones. The GDP of Ruili in 2020 is 70, 855 yuan, ranking the first in Dehong. Dehong's total value of import and export is 5, 379 million, ranking the second after Kunming. Thousands of Myanmar migrants come to Ruili for business trades, labor jobs and settlement in China. Myanmar migrants have played the important role in Ruili's economic growth. According to 2020 Yunnan Statistical Yearbook, Dehong's tertiary industry gains 30, 219 million, which constitutes 58.8\% in three industries. (Source: Yunnan Statistics Bureau, date: 2021-05-13) In Yang Ting's study, a questionnaire with 250 migrant migrant workers is conducted. She finds the percentage of migrant workers in service industry is $15.2 \%$, in which $4 \%$ of them work in massage parlors.

Although some researchers have conducted many research on Myanmar migrants in China, grassroots Myanmar migrants' multilingualism in workplaces has not been paid enough attention. Therefore, the thesis hopes to fill some blanks about it.

The thesis examines the interplay of national policies at the macro level, the employers' management at the meso level and Myanmar migrants' language practices at the micro level. When it comes to theoretical significance, the thesis adopts Spolsky's language policy theory and applies a critical sociolinguistic ethnographic paradigm. The study offers an emerging and mobile research structure for language management and grassroots multilingualism. Spolsky's language policy theory consists of language belief/ideology, language management and language practice. The thesis analyzes the language beliefs and practices of Myanmar migrant workers in a Chinese massage parlour, and the way that social factors influence their language practices and reshape their language beliefs. As for practical significance, the study sheds light on Myanmar migrants' language management and grassroots multilingualism in the context of globalization from below. The study provides implications on future language policy making, migrants integration and education for migrants of multilingual backgrounds.

The thesis contains five parts: introduction, literature review, methodology, results and conclusion. The first part introduces the research context of this study. A brief literature review on migrants and languages of current foreign and domestic research is presented in Part 2, and then points out the research gaps. Part three is methodological design, which gives definitions of language management and justifies the theory adoption. Methodology contains the thesis' research questions, research site choice, data collection method and main participants of the study. Part five is about findings, consisting of in-depth analysis of data. First it analyzes national level of language beliefs. Second, the thesis explores the language beliefs of management level and Myanmar migrants. Third, it includes Myanmar migrants' language practices and the challenges they are confronted with. Conclusions are given for further studies at the end of the thesis.

\section{Literature Review}

The literature review combs the empirical studies on migrants by the ethnographic approach. Then further focused on domestic research on Myanmar migrants. At last research gaps are provided.

\subsection{Current Foreign and Domestic Research}

Kamilla Kraft conducts an ethnographic research on construction workers. Kamilla's study discovers that a worker with "right" language gains social recognition, yet this kind of linguistic valuation brings differentiation with local and migrant workers. Han Huamei also adopts sociolinguistic ethnography, to explore the way that migrants with African and Chinese backgrounds expand their multilingual repertoires in Guangzhou. She argues that individuals' language repertoires are constrained by national and regional resources within world geopolitical order. Manju Shakya and Yunjeong Yang conduct a qualitative research with 13 Nepalese women who work as manufacture workers in South Korea. These migrants gain more confidence in new recognition and get empowered through migration. Li Jia investigates Myanmar ethnic minority students' language ideologies in learning Putonghua and educational trajectories in a borderland school. Myanmar ethnic minority students who have access to Putonghua have an agentive approach and capital to reposition their identity. The capital of Putonghua is increased through national polices in the borderland. Li Jia proves Myanmar students are confronted with exclusion, they have to mobilize linguistic and cultural resources to reposition and enhance their status. She concludes China's policies in border areas not only reinforce Putonghua as the standard but also valorise Burmese as the only legitimate language used for mutual communication. Ling Danxia studies the interplay of language policy, University management and language practices at a borderland University. She reveals the discrepancies between national language ideologies and actual learning challenges and suggests that it is imperative to deal with this challenges and asymmetries.

In Zhu Xianghui's research, Myanmar migrants in Thailand are mainly engaged in manufacturing, agriculture, domestic service or the marine industry. Chen Xue focuses on Myanmar migrant women and their intimate 
economic and emotional connections with their original families in Myanmar. By exploring their remittance prospect, she affirms the importance of cross-border women in transnational society, and China's positive influence on neighboring countries. Yang Ting explores new measures of Dehong under One Belt and Road Initiative context managing foreign immigrants. Tian Suqing analyzes the current service management situation of Myanmar migrants in Ruili City. Also in her the livelihood and living space of Myanmar migrants in China and Myanmar border cities, she gives the different descriptions of Myanmar's livelihood, living space and religious practice. Ma Juli and Sun Rui study Myanmar Kachin's religious life in Ruili. From their findings, Myanmar Kachin's transnational desires are mainly motivated by economy. Besides economy, religious organization has both positive and negative influences on immigrant Kachins. Participating in Christian activities is a symbol of expressing their ethnic identity. Li Xuan conducts a qualitative and quantitative study of Myanmar ethnic Chinese's family language policy within the framework of Spolsky's language policy and planning. She discovers national language policies and education policies influence their family language policy, which presents distinct national characteristics.

\subsection{Research Gap}

Recent foreign studies have drawn attention for Myanmar ethnic students and the importance of Putonghua in border areas of China. Also the impact of national policies on education and the discrepancies between language ideologies and language practices are revealed. As for the existing domestic research, more attention is paid to social management of Myanmar migrant workers or minority groups' integration. However, there are little studies on Myanmar migrant workers' language choices and language management.

\section{Theoretical Framework}

This part introduces theoretical concept of Spolsky's language policy by defining three layers rationales. Then it gives a justification to the adoption of Spolsky's theory. The aim of the thesis is to study the dynamic interplay of language policies at the macro level, meso language management at Ruili's massage parlour and Myanmar migrants' language practices at the micro level. The details of data collection are presented.

\subsection{Spolsky's Language Policy Theory}

In the 1950s has language planning begun and it revives in the 1990s. Bernard Spolsky divides language policy and planning into three parts: language practices, language beliefs and language managements. Language beliefs are people's views about the value and status of language, language varieties and language characteristics. The status and influence of a language or language varieties depend on the number and importance of language users and the social and economic benefits that the language can bring. Language management is authoritative individuals or groups take implicit or explicit measures to change the language practices and beliefs of participants who are in some domains. In Spolsky's Language Management, he discusses language in family, workplaces, education and religions. Language management is mutually influenced by internal and external domains and it is dynamic across time and space. Language practices refer to visible language behaviour and choices, including people's language characteristics and language varieties used. The interplay of language ideology/belief, language management and language practice are a dynamic pattern (see Figure 1).

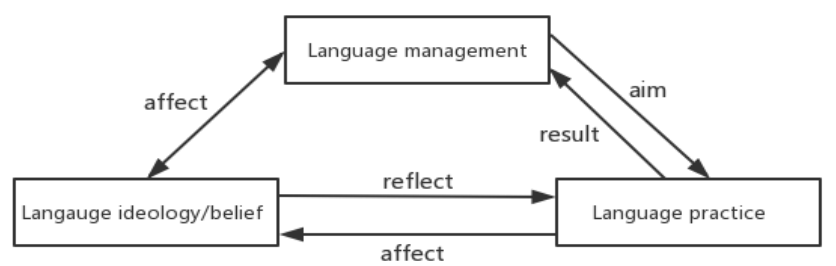

Figure 1. The interplay of three components in Spolsky' language policy theory

Spolsky's language management theory suggests the interplay of language practices, language beliefs and language management, which should be inspected from macro level (sociopolitical context, global or regional policies), meso level (local governments, markets or universities) and micro level (language investment and the family language policies). Multilingual practices in workplaces and language management have distinct commercial motivation. The strategies of transnational companies are setting up a lingua franca, multilingualism, language training, the machine translation and hiring outside translator.

This thesis explores the relationship among employees, employer and employees, employees and customers. Findings reveal the discontinuities or discrepancies between their language beliefs and language practices. Also 
the thesis adopts an intersection approach to reflect upon what can we do about language and migration. From findings, gender, nationality, ethnicity, religion and class are influential in migrants' language attitudes and choices. The thesis triggers policy makers' and stakeholders' consideration to migrants' settlement and integration.

\subsection{Justifications of Theory}

Spolsky's language policy theory is chosen as theoretical concept in this thesis. First, Spolsky's three-layered theory can offer an explanation of Myanmar migrants' multilingual repertoires. From the macro, meso and micro level can the interplay of migrants' language practices, language beliefs and language management be understood logically. The theory is suitable to analyze their language choices. Second, Spolsky's language policy theory is a mature and widely used theory in language policies (see studies of Ling, 2019; Bonacina, 2010; Mortimer, 2013; Ricento \& Hornberger, 1996; Mahammad, 2012). Third, Myanmar migrants' language choices and multilingualism in border areas are a dynamic mechanism, which needs researchers' more attention.

\section{Methodology}

This part includes the research approach, research site introduction, data collection process, participants' profile and analysis methods. The thesis aims to examine the interaction of national policies at the macro level, regional government' and employer's government at the meso level and Myanmar migrants' language practices at the micro level. The thesis attempts to answer research questions as follows:

(1) What language practices Myanmar migrants take? What social factors constrain or motivate their language practices?

(2) How they mobilize social resources to expand their multilingual repertoires and constitute their cross-border subjectivity?

(3) What challenges they are confronted with?

\subsection{The Critical Sociolinguistic Ethnography}

The critical sociolinguitic ethnography is chosen to apply in complicated multilingual research (Heller, 2009; Li, 2017; Li, Ai, \& Zhang, 2020; Li, 2020). The thesis applies a qualitative paradigm. Ethnography is the most significant method of doing qualitative studies. As Watson claims that "ethnography aims to study the behavior of people in a natural, ongoing environment, and researchers focus on interpreting these behaviors from a cultural perspective". To begin with, it gives an opportunity to participants observation in the research field (Sutton \& Levinson, 2001). Secondly, it is a dynamic investigation approach to investigate different language phenomenon (Hornberger \& Johnson, 2007). Thirdly, ethnography has been widely used in sociolinguistic and language study and been examined repeatedly. Li Jia (2017) uses a critical ethnography to reveal how Myanmar students mobilize linguistic and cultural resources to reposition their status. Li Jia, Ai Bin and Zhang Jie (2020) analyze the tensions and contradictions that Myanmar ethnic minority students experience on their multilingual practices in a borderland school. Therefore, it is a mature and adequate research method.

\subsection{Research Sitevbm}

A Chinese massage parlour in Ruili, Yunnan Province is chosen as the research site. The reasons can be listed as follows: first, China and Myanmar share an over 2,200 km long boundary, largely in the borderland of Yunnan, which means strategic meanings for mutual economic and cultural development. Second, millions of migrants from neighboring countries cross the border and fulfill their transnational aspirations in China. The chosen one aims at middle-class or grassroots customers, and the workers are all grassroots. Third, what makes this massage parlour different from others is that only employer and the manager are Chinese, and the rest of workers are all from Myanmar. Although Myanmar migrant workers come and go, staff composition does not change.

When it comes to the layout of the massage parlour, it has three floors with the first and second floor are used for business, and the third floor is Myanmar migrant workers' dormitory. The massage parlour targets middle and grassroots class customers, with simple layout but bright and clear atmosphere.

\subsection{Data Collection}

A longitudinal field work has been conducted since January, 2020. Data is collected from semi-structured interview, participant observation in and outside the massage parlour, field notes, document collection and online interactions. With my supervisor's introduction, I integrated in massage parlour successfully. During the field work, I kept field notes regularly and my supervisor gave me feedback in time in order to adjust the directions of study. Due to geological and epidemic constraint, additional online data like Wechat and Comments are also collected. Douyin is also an important resources in collecting data in the thesis. 


\subsection{Participants}

The field works have started from 2020. However, due to COVID-19 pandemic, some participants go back to Myanmar and are not allowed to come back to Ruili again. Table 1 only lists main participants' information.

Table 1. Myanmar Migrants' Profile

\begin{tabular}{|c|c|c|c|c|c|c|}
\hline $\begin{array}{l}\text { Partici- } \\
\text { pants }\end{array}$ & Gender & Age & Ethnicity & $\begin{array}{l}\text { Length of year } \\
\text { in China }\end{array}$ & Birthplace & Self-identified language backgrounds \\
\hline $\mathrm{P} 1$ & $\mathrm{~F}$ & 26 & Ethnic Chinese & 6 yrs. & Kutkai & Chinese, Myanmar \\
\hline $\mathrm{P} 2$ & $\mathrm{~F}$ & 25 & Palaung & 5 yrs. & Lashio & Palaung, Myanmar, Chinese, English, Tai \\
\hline P3 & $\mathrm{F}$ & 25 & Jingpo & 2 yrs. & Myitkyina & Jingpo, Myanmar, Chinese, English \\
\hline P4 & $\mathrm{F}$ & 22 & Jingpo & 3 yrs. & Moneko & Jingpo, Myanmar, Chinese, English, Tai \\
\hline P5 & $\mathrm{F}$ & 22 & Jingpo & 5 yrs. & Lwaigyai & Jingpo, Myanmar, Chinese, Tai \\
\hline P6 & $\mathrm{F}$ & 25 & Tai & 6 yrs. & Lashio & $\begin{array}{c}\text { Tai, Myanmar, Chinese, Jingpo, Palaung, } \\
\text { English }\end{array}$ \\
\hline P7 & $\mathrm{F}$ & 25 & Bamar & 4 yrs. & Mandalay & Myanmar, Chinese \\
\hline P8 & $\mathrm{F}$ & 20 & Jingpo & 2 yrs. & Lwaigyai & Myanmar, Chinese, Jingpo \\
\hline P9 & $\mathrm{F}$ & 20 & Palaung & 2 yrs. & Lashio & Myanmar, Palaung, Chinese \\
\hline $\mathrm{P} 10$ & $\mathrm{~F}$ & 25 & Tai & 5 yrs. & Lashio & Myanmar, Chinese, Tai \\
\hline $\mathrm{P} 11$ & M & 31 & Bamar & 3 yrs. & Mandalay & Myanmar, Chinese \\
\hline $\mathrm{P} 12$ & M & 22 & Jingpo & 4 yrs. & Maijayang & Jingpo, Myanmar, Chinese \\
\hline P13 & M & 24 & Palaung & 4 yrs. & Muse & Palaung, Myanmar, Chinese \\
\hline
\end{tabular}

P1 is ethnic Chinese who comes from Kutkai. She speaks the best Putonghua among Myanmar workers. P5 has been in China for five and a half years and worked in a massage parlour for more than two years. If there are many customers, she can serve four to five customers in one day. If not, she still can have one or two customers. Generally speaking, massage parlors are less crowded in the afternoon than in the evening. She likes playing Douyin in her spare time. P5 only speaks a little Chinese but she can not understand much Ruili dialect, nor read Chinese Characters. P7 is the only one who do pedicure and the only Bamar after her brother (P11) returned to Myanmar. P11 is 31 years old, still single. He comes to China and works in this massage parlour for two and a half years. Although they are all Bamar and brought up in the same family, P7 has more motivation to learn and speak Putonghua. As the result of her language investment in Putonghua, she is now the second popular massagist in the massage parlour and earns more than her brother.

\section{Results}

This part explores the dynamic interplay of national and regional policies about managing Myanmar migrant workers at a macro level, employers' management at a meso level and Myanmar migrant workers' language practices at a micro level. Grounded on Spolsky's language policy theory, the thesis starts with the examination of national and regional language policy, and then focuses on language management of employers. Myanmar migrant workers' language beliefs, language practices and the discrepancies are revealed.

\subsection{Language Beliefs}

According to spolsky, language beliefs are beliefs of language. A speech community values what kind of language varieties. A speech community may share similar language beliefs. This section examines various language beliefs that different levels hold.

\subsubsection{Language Beliefs at the Macro Level}

At the beginning of 2020, President Xi was on a state visit to Myanmar. President Xi reviewed Myanmar's military troops, and joined in 12 activities. This is the President's visit to Myanmar again in 19 years. President's speaking and visiting show the importance of Myanmar. Also it draws Myanmar's attention of China and Chinese. Myanmar migrant workers at the massage parlour are barely know about the diplomatic affairs. The News channel broadcasts the meeting between Myanmar' and China's leaders. Workers are not concerned about the news, but they are excited by seeing their national leaders, U Win Min and Aung San Suu Kyi, they got excited.

Q(uestion): Do you like Aung San Suи Kyi?

P2: Yes, we all like Aung San Suu Kyi in Myanmar. 
Q: Why?

P2: I can't say which is good and which is bad.

Q: But you all like Aung San Suu Kyi?

P2: Yes, who do you like in China? Do you have a boss? Like Aung San Suu Kyi in our Myanmar.

$Q$ : Then ours is President Xi.

P2: Oh, you people don't like to be noisy in China. (here "noisy" refers to fighting)

Myanmar is an important country in One Belt and Road Initiative. President Xi's visiting and speeches address China's respects towards Myanmar and is also a soft power projection to neighboring countries.

\subsubsection{Language Beliefs at the Meso Level}

In terms of policy, the Dehong State Education Bureau treats Myanmar migrant workers equally. However, not all children of Myanmar migrant workers can be enrolled in Chinese schools. If a child of Myanmar migrant worker who only speaks Myanmar wants to study at the local school in Ruili, these school-age children need to make up for their preschool education Education, starting from listening and speaking of Chinese. The regional policies at the meso level emphasize the importance of Putonghua to get better education, which leads more Myanmar migrant workers to encourage their children to be bilingual or multilingual.

Main workers at the massage parlour can speak service-oriented language. Most of them receive low levels of education, who have weak market competitiveness, and have basically no labor technical training. Most of them are low-end laborers who can only engage in heavy manual labor or service work with low skill requirements at China's border town. Even if few managers force them to speak Putonghua, they learn that Putonghua is the gateway to more salary.

\subsubsection{Language Beliefs at the Micro Level}

Myanmar migrant workers believe the proficiency of Putonghua (Ruili Fangyan) can benefit them economically and socially. From the interviews with them, they admit some successful examples of their friends encourage them to learn Putonghua. P2's statement shows her language beliefs:

Learning Putonghua is a good thing. I do not know why, but I know it is good. I learn Putonghua to type. I want to send messages to my friends. I do not want to write on keyboard or speak to phone and transform it into Putonghua. I want to type like English words, a,b,c. (P2)

P2 does not know what learning Putonghua would bring her, and why she should learn it. She saw what her friends' successful experiences and concluded learning Putonghua is a good thing. P2 can speak good Putonghua than most of workers in massage parlour because of her previous job experiences. She went abroad, Singapore and Vietnam, and went to Mangshi, a city near Ruili for work. Now she wants to learn Chinese characters. She claims learning Chinese Characters is to send messages. The further reason is to build her social networks.

Female Myanmar migrant workers are possible to marry a Chinese man in Ruili if she can understand daily communication with the locals. Or they can have the right to change their jobs with higher proficiency of Putonghua. Since the outbreak of COVID-19, live streaming has become a popular and profitable occupation nationwide. And in Ruili, a city famous for its jade business, live streaming jade business rise in response to the proper time and condition. Owing to advertising needs, more Myanmar anchors are needed. Undoubtedly, Putonghua capability is paramount requirement. Learning Putonghua can bring a much higher income for them. Also the experiences like stars can bring satisfactory to their social needs.

For instance, P11 has worked in the massage parlour for two and a half years, he knows some vocabulary related to professional needs. When I ask the reason for coming China, he answered:

"It is better to make money in China (Ruili). Compared to Myanmar, the salary is higher. Although my salary earned in China is not very high, it is still higher than in Myanmar. There are many massage parlours nearby, I chose to work here because my brother used to work here. About future I would continue to work in China. My aspiration is to come to China and make a lot of money. When I earn enough money, I would return to Myanmar and live a good life. At first I want to do jade business, because jade resources is rich in Myanmar. However, I do not understand Chinese. Finally I gave up." (P11)

P11 is a very shy man, therefore, he seldom initiates a conversation with his customers. Being unable to speak Putonghua constrain his career development greatly. P7 is the sister of P11. Unlike P11, P7 can massage five to six customers in one day. In a month she can make six thousand, much more than her brother. Regarding the commission, employer and Myanmar workers take fifty fifty in the massage parlour. When asked about where to 
stay in the future, P7 said:

"I want to go back to Myanmar. China is good, but Myanmar is also good. Chinese man is good, but Myanmar man is also not bad. I will marry a Myanmar man”(P7)

P7 is a Bamar people, who presents a stronger affections towards Myanmar. During the observation, I found that P12 and P7 had the same style of manicure, just like Myanmar flag. Besides that, most of Myanmar migrant workers are filial. They come to China not only hoping to live a better life themselves, but also carrying the hope of the whole family. They will send their salary home to subsidize the family. For example, P6's WeChat profile was a photo of herself and her mother. She was very happy when she got salary. She says she can buy her mother anything that her mother likes.

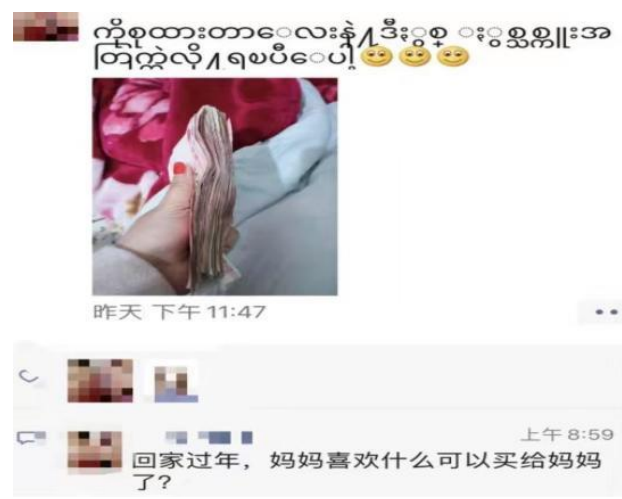

Figure 2. P6' Wechat Comments.

Language is a standard to classify insiders and outsiders. Being able to speak Putonghua can help Myanmar migrants a lot to integrate in China. Education is an important approach to present and reshape language beliefs. Likewise, from Myanmar migrants' views about education can we know their language beliefs.

P2 has married to a Myanmar, and gave birth to two daughters. Here is an interview with P2 on children's education:

"I don't know whether to let children go directly to elementary school or kindergarten in China or Myanmar. Your (Chinese) children here (in China) go to school when they are three and four years old, and ours (Myanmar) is five years old (going to school). It's okay to go to Myanmar school, because it's our hometown over there. You can also learn Chinese and Myanmar there." (P2)

Being able to learn Chinese in Myanmar can adapt to the needs of her children whether working in Myanmar or China in the future. Therefore, there is no difference in going to school in China or Myanmar. Myanmar is their home, so P2 prefers to let her The child goes to school in Myanmar. When it comes to P4, she talked about her previous education experiences and showed obvious inclination to learn Putonghua:

"Our family has no money. I only finished high school. In Myanmar we can stop for a period of time and continue to study, such as to university. When it comes to China, it is more comfortable and suitable for living, there (Myanmar)... I feel that the living environment and living standards are too poor and too low. The salary in Myanmar is not as high as here, usually 800 or 1,000 yuan, and the teachers are only 800 yuan. I probably want to stay in China in the future, and find a boyfriend here. But I am not sure if I can find one" (P4)

From participants' observation and interviews with Myanmar migrant workers, it finds out that massage parlour serves as a start and springboard for their higher-paid jobs and more promising life. For example, in the interview with P3, she states:

"I don't want to work here anymore. I'm going to a big store. It's a bit tired and low-paid. I want to change my job, but I can't speak Chinese. My Chinese is not so good. Although there are jobs requiring not so high proficiency in Chinese, I wanted to sell raw gemstones (to make jade). Currently I don't know much about the jade industry, about the jade assistant, the anchor. I just want to do that job. It is not easy to be a live streaming anchor by oneself. But if I have jade resources, it would be much more convenient. My brother used to be in Pagan (to do this business)." (P3)

Myanmar migrant workers said that Chinese don't want to do this massage job, because Chinese don't want to do this low-graded job. When there are few guests, they can watch videos, play Douyin or games, or chat through Myanmar Facebook, WeChat, doing everything they want to spend time. 
However, P9 is aspiring girl, who brought a small notebook with Chinese alphabets she learned from Facebook in her spare time. A video posted on Facebook teaches Chinese in a way of interweaving English, Myanmar and Chinese. P9 has learned herself for a week, and asked how to write 1-23 in Chinese, which was not taught in the video. And ask for after learning the letters, what should be learned next. Now she can recognize and spell Chinese. She believes learning Chinese can bring great changes to her life.

\subsection{Language Management}

Language management refers to formulating languages by policies. It attempts to influence a speech community's language choices. Language management in family, religion, school and workplaces are included. In this section, national language management, employer's management and Myanmar workers' language management are explored.

\subsubsection{Language Management at the Macro Level}

On January 7, 2012, Ruili took full advantage of its policies and tried first, and formulated the "Interim Measures for the Service Management of Overseas Inbound Persons in Ruili City (for Trial Implementation)", tailored relevant systems, and actively explored standardized services for Myanmar management. On June 15, 2013, Ruili Foreign Personnel Service Management Center was established. It is a "one-stop" service management innovation model for foreign immigrants that is jointly operated by health (quarantine), human resources and social security, public security, border defense and other departments to standardize management of entry of Myanmar nationals. In August 2014, the Dehong prefecture government passed the "Interim Measures for the Management of Migrant Workers from Foreign Borders in Dehong Prefecture", which provides relevant basis for the standardization of labor management of Myanmar nationals across the prefecture. Subsequently, as a supporting policy, the Dehong Prefecture Human Resources and Social Security Bureau uniformly produced and issued the "Registration Certificate for Hiring Overseas Frontier Workers" and the "Dehong Prefecture Overseas Frontier Workers Registration Certificate" to further explore the standardization of services and management of inbound migrant workers' jobs. Myanmar workers working in China have to change their certificates once a month.

By establishing relevant management systems, the national and regional government design a suitable system for managing migrants in China. However, no specific or direct requirements are designed for Myanmar migrants. The actual situation is that Myanmar migrants needs to learn Putonghua on the condition that he or she were alone working in China and did not have friends as interlocutors. A conclusion is drawn that so far few national policies have direct influence on Myanmar migrants' language management.

\subsubsection{Language Management at the Meso Level}

As for national policies' influences on managers at the meso level, there are article stipulating that:

"Employing units (economic organizations and individuals) shall foreign border residents hired to purchase accidental injury and industrial injury commercial insurance. If not, the employer (economic organization and individual people) shall bear the responsibility for accidental injury and work-related injury compensation by themselves."

Article 19 also regulates that according to laws, employers should train migrant workers before work: "Employers shall carry out legal actions on the foreign border residents they employ regulations, production safety, skills and technology training". When it comes to the massage parlor, the language practices of employer in the massage parlour are manifested during the interviews. When the employer is interviewing new workers. Nothing is particularly stressed other than the capability of language.

I do not want any very beautiful girls or handsome boys. Only if you behave yourselves, do not argue with customers or fight with colleges. If something unhappy or annoying happens, try to speak politely. If you still can not solve it, come to me and I will do the talking. Even if you do not have any skills, do not worry. I will teach you, but being able to speak Putonghua (or Ruili fangyan) is very important. You should know, those who can speak Putonghua can have a good relationship with customers. The more customers you have, the more you earn (The massage parlour employer).

This conversation happened when a female Myanmar migrant introduced her friends to work at this massage parlour. This female Myanmar migrant can speak Putonghua as well as a native Ruili people. But two of her friends can barely speak Putonghua. They are timid in front of the employer. 
The manager said all the Myanmar workers in the massage parlour have temporary Chinese residence permits. To economic factors, the employer makes Myanmar workers buy watch to check time. As mentioned in 4.2, the decision that employer lets Myanmar migrant workers live in the third floor is cogitative and economical. With Myanmar migrant workers controlled in the store at night, employer can ensure their safety, keeping them from running away and making trouble. What's more, Myanmar workers can serve as doorkeepers in case there are thieves breaking in. Giving them a place to live for free can also attract more workers to work here. On the other hand, employer can prolong the working time without concern that Myanmar worker would complain.

\subsubsection{Language Management at the Micro Level}

Language management can root from family language policy, just as P6 does. P6 is from Lashio, Myanmar. Even if she just finished junior high, she is capable of speaking Tai, Myanmar, Putonghua, English, Jingpo and Palaung. P6's Chinese is very good. Her language and accent are very similar to that of the Ruili locals. She is very talkative and often takes the initiative to chat with customers.

"My mother is a Han people and My father is a Tai in Myanmar. I have been in China for six years. I used to work as a massagist in a bigger hotel (which she called a big store). And massage techniques are different in different places. The techniques taught in this massage shop are different from the previous ones. Every Myanmar workers have to do pre-job training for about a week, identifying acupoints and massaging." (P6)

I asked her how she learn Putonghua. She answered:

"I talk to people slowly, and by talking and practicing I can speak Putonghua. There are also people who speak Putonghua in my hometown. My friend taught me Pinyin, and I can also write some characters. Through Chinese television series, Douyin and games can I learn Putonghua." (P6)

Because of their status and class, they can not get access to formal and standard language learning opportunities. They can learn language through the daily communication withe customers or self-teaching.

The massage parlour had been renovated by them before Spring festival. They painted the walls during the Chinese New Year and changed the first floor. P6 said the boss was stingy and didn't hire anyone professional to do it, but made them do it themselves. They have been cleaning for three or four days, but their employer did not paid them wages. Most of the Myanmar migrant workers at the massage parlour hold the same attitude towards the employer, like P2:

"The boss didn't come usually, I didn't know what he was busy with. We told him to have a holiday tomorrow, but he would not let it go. He used to be more stingy and not giving us one day (New Year) holiday. He is too stingy. I said let us rest for a week this year. He said that some there would be more customers during holidays. The employer also said that he would start a night shift because of too many guests recently." (P2)

Myanmar migrant workers do not understand and complain about the management. They would discuss the employer in Myanmar so that the employer would not understand them.

\subsection{Language Practice}

Language practices are visible behaviors and language choices. In grassroots multilingual workplaces, Myanmar migrant workers' language practices and reality have some discontinuities, which bring some challenges to Myanmar workers.

\subsubsection{Language Practice at the Meso Level}

This massage parlour is owned by a male Chinese and he hands over the manage power to his relative, who is a disabled girl. Besides the employer and the manager, the rest of workers are all Myanmar migrants. The employer makes the manager live in parlour and manage Myanmar migrant workers' life and work. Although the statuses of male employer and female manager are both higher than Myanmar migrant workers, they present different language practices.

Employer shows no concern with what his workers say, even though they are cursing him in Myanmar. Instead he would respond proudly, "I can not understand you, no matter what you have said. I can not understand Myanmar, unless you teach me Myanmar first". Employer solves the situation with a kind of humor and irony. Different with employer, the female manager adopts a totally converse strategies. In order to adapt to Myanmar workers, she learns to speak Myanmar. Less than one year after her work, she can speak Myanmar so well that new Myanmar workers have assumed her as a Myanmar people. 
Their different language practices are the result of their needs. As a employer who do not have to live with Myanmar workers, he only comes to check occasionally. With his trustworthy relative as the manager in massage parlour which is one of his business, so he needs to spend more time on other more profitable business. However, the manager is confronted with more than fifteen Myanmar migrant workers. After work she is shut indoors with them, who can speak limited Putonghua. What's worse, she is disabled. What if some conflicts happen, she can do nothing without the proficiency of Myanmar. Due to the need to communicate, to entertain and to manage, the manager mastered Myanmar through daily practices with Myanmar workers.

Inevitably, there would be some Myanmar migrants escaping from the massage parlour secretly. They told the manager some workers are going to buy things, and never returned.

Q(estion): If this situation often occurs? When they secretly leave and never come back?

M(anager): Yes, it is quite common. They went out, saying to buy things to eat or ask for a leave, and they would never return.

Q: Are there some exceptions? And why they leave?

M: Some would come back several days later, not saying where they have gone. Probably they can not get used to it. What's more, they can not speak Putonghua. Maybe they miss home. But when they do not have money, they would come back to work here.

When it comes to their language practices with customers, their language practices are similar. They both speak Putonghua (Ruili Fangyan) with customers. In the massage parlour, it is common to hear intertwined dialogues of Myanmar and Putonghua. Just as they are informed by the manager: the more customers they have, the more they earn.

\subsubsection{Language Practice at the Micro Level}

When field works starts, I saw one of P2's daughters in the massage parlour. The little girl is excellent in language within her 4-year-old age. The girl can now speak Palaung, Myanmar, and a little Putonghua. When I asked her age, she answered me in Chinese. She used actions to prove she understood me. When P2 comes, she "blames" the girl in Palaung, probably meaning "why you are so voracious". The P2 teaches the child to thank me (P2 is speaking in Palaung), and the girl submissively thanked me in Putonghua. The child would attract my attention intentionally by bouncing on the chair or directly called me "Mama". I did not quite understand, assuming she was calling her mother. Then a girl told me: "She (the child) does not speak Chinese very much, and just now she is calling you 'sister' in Myanmar". Before she went to find her mother, she said goodbye to me in Putonghua and flew me kisses, which makes other workers laughing. From the little migrant girl, it is drawn that she was brought with multiple languages and has the awareness of translanguaging.

The massage Parlour in Ruili is a place containing multiple languages. To earn more money, Myanmar migrant workers, especially girls are very active to learn Putonghua. And they utilize various methods. Some learn Putonghua through daily practices with customers, manager or friends. Some choose to learn Chinese and Chinese characters in bilingual schools. Learning Putonghua from social medium is an emerging approach for Myanmar migrant workers. With Douyin, facebook and some video players, they enjoy themselves in making and sharing short video, by which they can build larger social networks.

On the first day, hearing two Myanmar workers are playing the guitar, using phones to listening to music, singing English and Myanmar Songs. When they are free, male Myanmar workers in the massage salon will play games on the phones. From playing games, they can learn to use the expression, such as, supplies 、 gathering 、 winning, and taking photos. The manager also likes to playing games. Female Myanmar migrants workers spend a lot of time in chatting on phones, making Douyin video, or go shopping. According to management, they can go out for an hour a day, but not at night. In the shop Myanmar workers communicate in Myanmar or their own minority languages. It expresses the intimacy of the same race and the isolation of the Other, and prevent customers and employer from understanding what they say.

Because of her excellent Putonghua proficiency, P1 has many regular customers, who can visit her every day. She worries the least about her salary. She can even choose which customers to serve. When her regular customer comes, they play phones together. The man asks P1 to massage his back. P1 pinches the customer with her hand in his clothes. P1 uses coquetry to ask the man to bury snacks for her. Things like that often are seen in massage parlour. Establishing an intimate relations with Chinese customers are a necessary move if Myanmar migrant workers want to marry a Chinese man and change their status. And P1 also shows her filial piety to her mother in Putonghua: 
"Sometimes customers come late, and we have to serve them even after half past twelve. During the New Year, I didn't want to stay in Ruili. There is no money to make, and I want to go home, returning to Myanmar. My mother is busy cleaning at home. I want to help her."(P1)

From this kind of statement in Putonghua, she can establish a better image of herself and earn more publicity among customers.

\section{Characteristics:}

\section{Gender influence}

Putonghua Proficiency influences salary and gender influences their motivation to learn Putonghua. In the massage parlour, female workers' salary is higher than males. Female workers have a wider range of customers and regular customers. Male workers either train their massage skills to make more money or work at will. P11 is a diligent male worker. He is the brother of P7, and he only stays in China for more than two years. He is an introverted man and barely speaks to customers. He only speaks Myanmar with other workers and can say some basic communicative sentences, like "Is the water hot enough?", "please sit here". Myanmar migrant workers without Putonghua proficiency are afraid of getting complained by customers.

Gender is an influential factors which affects Myanmar migrant workers' language attitudes and practices. Ethnicity also has impacts on their transnational aspiration and language practices. Their migrants status constrains their social networks and resources, so they tries to expand their social networks by social media, like Douyin, Plamchat, and Facebook. Also they are intentionally transforming their customers into their friends who can offer them helps when needed.

Most of the boys in Myanmar stay at home and let the girls come to work in China. This is because of gender advantages or other considerations. P2's elder cousin first worked in the store, and later asked his two younger sisters to work here, because he can not earn as much as P2 does. Or their family may hope that girls can find a Chinese to marry. Girls in Myanmar are very filial to their families and will send most of their wages back home. Male workers admits before that girls earn more than them, which makes them jealous.

Manager Served an Interlocutor

Because of the limited Putonghua level, when Myanmar migrant workers encounter some questions they can not understand, they would ask the manager for help in Myanmar. Manager would communicate with them in Myanmar and ask customers in Putonghua. Not only Myanmar migrants benefit from that, but also the manager get empowered by this interlocutor job. She becomes more confident from the communication with customers and migrant workers.

Using some lies to cover themselves

Myanmar migrant workers are good at using lies to gain a more advantage position of themselves. Sometimes they would lie to their regular customers, like "I am sick" (P4). But actually she did not want to get up to serve them. Or they may directly refuse to work, "I am busy, having no time"(P2). In fact, P2 just wanted to watch her Chinese TV series. P2 would ask for leave to renew her certificate, and did not return to work on time, lying that the certificate is not renewed yet.

Challenges

Sex Harassment

Owing to the speciality of massage, it is common for Myanmar migrant workers are discriminated and encountered sex harassment from not only Chinese but also Myanmar customers. Many girls suffer from sex harassment during their works, for instance:

$$
\text { P2: all right }
$$

C(ustomer): It's not enough time yet.

P2: You just said yes (P2 has put up with the harassment for long and become a little angry. )

C: Not yet. ... I don't want to give money anymore, I don't have any today. (He opened the curtain and left, while talking) Today there is no money, have you heard it?

P2: (completely angry) what! Are you here for a massage or come to touch us? Why are you holding my hand? My hands are here to massage, don't touch (in Putonghua).

The male guest is still playing tricks that he has no money today. They quarreled until downstairs. P6 said the man often comes, sometimes speaking alone or being angry suddenly. He would call whoever he wanted to serve 
him. P6 said his harassment is not only to workers, but also to other customers. One time a female customers just put on her clothes after back massage, the male customer came to peek and scolded the female customer. And the female guest scolded him in return. But all about this harassment, the employer did not handle this issue and warn the male customer.

Medical care

Medical care is another challenge Myanmar migrant workers confronted with in China. If they catch a cold, and they would buy medicine in a nearby drug store, which is opened by a Myanmar.Their Chinese was not good, so they couldn't describe their symptoms to the doctor.

"We used to go Muse for medical treatment. But now because the country is closed, we do not have access to Muse anymore, which makes medical care very troublesome. For me, I have to endure the illness till it recovers. If we are gone in the morning, even for treatment, the employer will not let me ask for leave again. So I say it is more troublesome in China. Now because of the epidemic, there is no need to stamp it. We can only go out of the country, but we can't enter any longer. Although I wanted to go back to Myanmar, I couldn't." (P2)

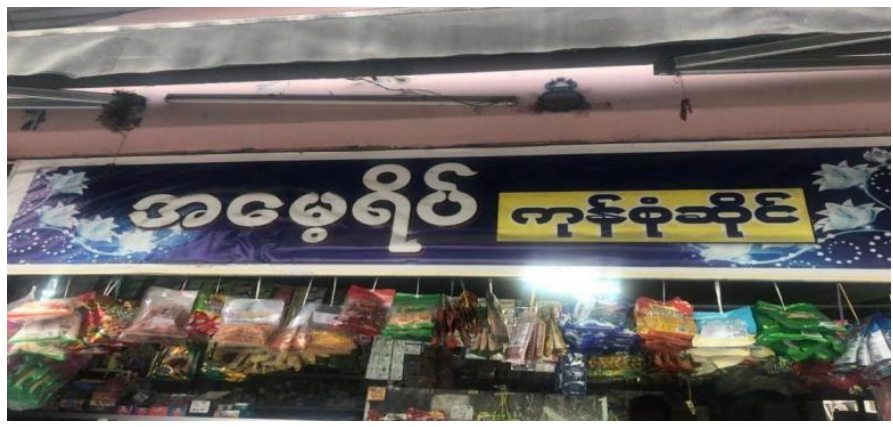

Figure 3. Myanmar drug and snack store

When P2' Chinese boyfriend took her to see a movie, I accompanied and did participant observation. When P2 saw that a newborn was put in an incubator during the epidemic. She got confused at first.

P2: Is this feeding milk?

A(nswer): Yes.

P2: It's so cold and nurses don't cloth the children.

A: It's insulated, kids don't need to wear a lot.

P2: Chinese hospitals are so great, taking care of children so good.

She did not know an incubator, then she told me her story of bearing two children. She did not use such medical equipment, and after the baby born, she went home immediately.

\section{Conclusion}

The study investigates the interplay of language management of national polices at macro level, employer's management at meso level and language practices at micro level. Findings reveal Myanmar migrant workers' multilingual repertoires and the features of their language practices. The thesis draws attention to the challenges Myanmar migrant workers encounter, which needs more studies to find ways to solve these challenges. In reality some Myanmar married for years but still were considered as outsiders and foreigners. They need more attention. Their identification and temporary residence permits need to be stamped once a week. Myanmar migrant workers rely on the manager to understand customers' need, and the manager also participates in discussions in Myanmar, in order to blend in with them. No matter what ethnic groups they are, they are from the same country when they speak Myanmar. Using Myanmar will increase intimacy and reduce the feeling of loneliness in a foreign land. In addition, communication in Myanmar is convenient for communicating some content that they don't want people to understand, such as complaints to the boss and mockery of the guests. Language can shorten the distance between them and the guests, and at the same time is a barrier, a kind of protection, so that they can say what they want to say.

The present study has some limitations. First, the national language beliefs on Myanmar workers are not sufficient. Second, the participants are not balanced in male Myanmar migrant workers' gender, because of the author's gender and age barrier. Third, the field work continued no more than three months each time because 
the author has to return to school.

This thesis shed light on Myanmar migrant workers' multilingualism. It presents the challenges Myanmar workers encounter, and future study can focus on the solution to them. Policymakers can enhance the national policies and migration education.

\section{References}

Bonacian, F. (2010). A Conversation analytic approach to practiced language policies: The example of an induction classroom for newly-arrived immigrant children in France (Doctoral dissertation). Retrieved from http://hdl.handle.net/1842/5268

Chen, X. (2020). Daughters of Myanmar: Remittance practice and emotional connection of female migrant workers in Ruili. The World of Alterity, (1), 191-208.

$\mathrm{Gu}, \mathrm{M}$. Y. (2008). Identity construction and investment transformation - college students from non-urban areas in China. Journal of Asian Pacific Communication, 18(1), 49-70. https://doi.org/10.1075/japc.18.1.04gu

Han, H. M. (2013). Individual Grassroots Multilingualism in Africa Town in Guangzhou: The Role of States in Globalization. International Multilingual Research Journal, $7(1), \quad 83-97$. https://doi.org/10.1080/19313152.2013.746803

Harzing, A., \& Feely, A. J. (2008). The language barrier and its complications for HQ-subsidiary relationship. Cross Cultural Management, 15(1), 49-61. https://doi.org/10.1108/13527600810848827

Heller, M. (2009). Doing ethnography. In L. Wei, \& M. Moyer (Eds.), The Blackwell guide to research methods in bilingualism and multilingualism (pp. 249-262). Oxford: Blackwell Publishing Ltd.

Hornberger, N. H., \& Johnson, D. C. (2007). Slicing the onion ethnographically: Layers and spaces in multilingual language education policy and practices. TESOL Quarterly, 14(3), 509-532. https://doi.org/10.1002/j.1545-7249.2007.tb00083.x

Kraft, K. (2017). Constructing migrant workers: Multilingualism and communication in the transnational construction site (Doctoral dissertation). Oslo: University of Oslo.

Li, J. (2017). Social Reproduction and Migrant Education: A Critical Sociolinguistic Ethnography of Burmese Students' Learning Experiences at a Border High School in China (Doctoral dissertation). Retrieved from https://www.languageonthemove.com/wp-content/uploads/2017/05/LI_Jia_Social_reproduction_and_migra nt_education.pdf

Li, J. (2020). Transnational migrant students between inclusive discourses and exclusionary practices. Multilingua, 39(2), 193-212. https://doi.org/10.1515/multi-2019-0125

Li, J., Ai, B., \& Zhang, J. (2020). Negotiating language ideologies in learning Putonghua: Myanmar ethnic minority students' perspectives on multilingual practices in a borderland school. Journal of Multilingual and Multicultural Development, 41(7), 633-646. https://doi.org/10.1080/01434632.2019.1678628

Li, X. (2020). Study on language planning of Chinese family in Myanmar - case of Chinese community in Mandalay (Unpublished Master's thesis). Nanjing University, Nanjing, China.

Ling, D. X. (2019). The interplay of language policy, university management and language practices: An ethnography of Myanmar majors' learning experiences at a China's border university (Master's thesis, Yunnan University, Kunming, China). Retrieved from https://kns.cnki.net/KCMS/detail/detail.aspx?dbname=CMFD202001\&filename=1019174760.nh

Ma, J. L., \& Sun, R. (2018). A Study on the Religious Life of Myanmar Kachin People in Ruili, Yunnan. The World Religious Cultures, (3), 76-82.

Mahammad. A. K. (2012). Social Meanings of Language Policy and Practices: A Critical Linguistic Ethnographic Study of Four Schools in Pakistan (Doctoral dissertation). Retrieved from https://ethos.bl.uk/OrderDetails.do?uin=uk.bl.ethos.658057

Mathew, G., \& Alba Vega, C. (2012). Introduction: What is Globalization from below? In G. Mathews, G. L. Ribeiro, \& C. Alba Vega (Eds.), Gobalization from below: The world's other economy (pp. 1-17). London, England: Routledge.

Mathews, G. (2011). Ghetto at the center of the world: Chungking mansions. Chicago, IL: University of Chicago Press.

Mortimer, K. (2013). Communicative event chains in an ethnography of Paraguayan language policy. 
International Journal of the Sociology of Language, 60-172. https://doi.org/10.1515/ijsl-2013-0005

Ricento, T., \& Hornberger, N. H. (1996). Unpeeling the onion: Language planning and policy and the ELT professional. TESOL Quarterly, 30(3), 401-427. https://doi.org/10.2307/3587691

Shakya, M., \& Yang, Y. J. (2019). Migration as a window to empowerment: Nepalese women's experiences in South Korea. Gender \& Development, 27(1), 105-122. https://doi.org/10.1080/13552074.2019.1570732

Sutton, M., \& Levinson, B. A. U. (2001). Policy as Practices: Towards a Comparative Sociocultural Analysis of Educational Policy. London: Abled.

Tian, S. Q. (2017a). Research on the present situation of service management of Burma nationality people in Ruili. Journal of Hubei University of Police, (1), 37-41.

Tian, S. Q. (2017b). Means of livelihood and living space of registered Burmese nationals livingin the Towns in the Sino-Burmese border area - based on an investigation in Ruili, Yunnan. Journal of Ethnology, (1), 75-83, 119-121.

Watson-Gegeo, K. A. (1998). Ethnography in ESL: Defining the essentials. TESOL Quarterly, 50(2), 472-474. https://doi.org/10.2307/3587257

Wen, Q. F. (2016). Producing language qualified personnel for "the Belt and Road Initiatives". Chinese Journal of Language Policy and Planning, (1), 26-32.

Yang, T. (2018). Research on the public security management of foreigners in Dehong prefecture under "One Belt and Road Initiatives" (Master's thesis, Yunnan University of Finance and Economics, Kunming, China). Retrieved from https://kns.cnki.net/KCMS/detail/detail.aspx?dbname=CMFD201802\&filename=1018088149.nh

Zhu, X. H. (2020). An analysis on Thailand's management of the Myanmar migrant labor community. Journal of World Peoples Studies, (4), 21-36.

\section{Copyrights}

Copyright for this article is retained by the author(s), with first publication rights granted to the journal.

This is an open-access article distributed under the terms and conditions of the Creative Commons Attribution license (http://creativecommons.org/licenses/by/4.0/). 